\title{
The Effects of Balance Training with Functional Electrical Stimulation on Balance and Gait in patients with chronic stroke
}

\author{
Eunji Kima, Kayoon Mina, Changho Songa

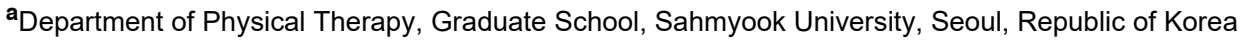

Objective: The purpose of this study was to examine the effects of balance training with Functional Electrical Stimulation (FES) on balance and gait in patients with chronic stroke.

Design: A cross over design

Methods: Nine patients with stroke were recruited into this study. They were measuring their balance ability and gait ability. The intervention "A" included 4 weeks of balance training with Functional Electrical Stimulation (FES) for $40 \mathrm{~m} / \mathrm{d}, 3 \mathrm{~d} / \mathrm{wk}$. Intervention "B" included 4 weeks of balance training with placebo Functional Electrical Stimulation (FES) for $40 \mathrm{~m} / \mathrm{d}, 3 \mathrm{~d} / \mathrm{wk}$. Of the 9 patients who completed the study, 5 were randomly assigned to" group A-B", and 4 to group B-A. The crossover occurred after 4 weeks.

Results: Following are the specific results of balance training with Functional Electrical Stimulation (FES) on patients with chronic stroke. First, patients who received treatment A showed improvement compared with patients who received treatment B in static balance. There were significant decreases in anterioposterior, mediolateral postural sway extension and velocity moment $(p<0.05)$ with their eyes opened and closed conditions. Second, they had significantly improved in dynamic balance $(p<0.05)$. Lastly, there were also improvement in their gait velocity and cadence $(\mathrm{p}<0.05)$.

Conclusions: These findings suggest that, the Functional Electrical Stimulation (FES) combined with balance training more effectively improves the balance and gait ability, I'm convinced that it could be actively used in clinics added to the conventional physical therapy in the future.

Key Words: Electrical stimulation, Stroke, Postural balance, Gait

\section{서론}

연구의 배경 및 필요성

뇌졸중은 세계적으로 주요 사망과 장애의 원인이 되는 질환으로[1]. 이중 사망하지 않고 생존하는 뇌졸중 환자는 약 $66 \%$ 의 신체기능 장애와 $75 \%$ 의 일상생활 장애를 가지 게 된다[2]. 특히 만성 뇌졸중 환자에게서 많이 나타나는 균형, 보행능력의 소실은 환자가 살아가기 위해 필요한 일 상생활에 장애를 초래한다[3].

만성 뇌졸중 환자에 있어 균형능력을 감소시키는 원인 은 인지기능, 근력, 관절가동범위의 저하 이외에도 비정상 적인 근긴장도, 비협응적인 움직임, 감각통합 능력의 결여 등이 있다[4].
근력 저하는 균형능력과 보행능력 감소의 주된 원인으 로써 만성 뇌졸중 환자, 척수 손상, 외상성 뇌손상과 같은 중추신경계 질환 환자들뿐만 아니라 근골격계 질환 환자, 노인에게서도 잘 나타나 사지의 수의적 움직임 조절, 자세 조절에 대한 장애를 갖게 하는 주요 요소이다[5].

만성 뇌졸중 환자들에게 근육의 약화가 일어나게 되면 type II 근섬유가 줄어들고, 신경전달 속도가 느려지게 되 어 최대로 근육이 수축하는 시간이 지연되게 된다[6]. 이러 한 약화가 균형을 조절하는 주요 근육인 전경골근, 비복근, 대퇴사두근, 슬괵근에 일어나게 되면 균형능력 감소에 직 접적인 영향을 끼치게 되는 것이다[7].

만성 뇌졸중 환자들의 손상 측 신체의 근력저하는 움직 임의 제한을 가져와 균형능력 감소가 나타나고 이는 낙상의

Received: Feb 16, 2021 Revised: Feb 24, 2021 Accepted: Feb 24, 2021

Corresponding author: Changho Song (ORCID https://orcid.org/0000-0002-5709-3100)

Department of Physical Therapy, College of Health and Welfare, Sahmyook University, 815, Hwarang-ro, Nowon-gu, Seoul, Republic of Korea Tel: (82 for International)10-8890-1087 Fax: E-mail: chsong@syu.ac.kr

This is an Open-Access article distributed under the terms of the Creative Commons Attribution Non-Commercial License (http://creativecommons.org/licenses/ by-nc/4.0) which permits unrestricted non-commercial use, distribution, and reproduction in any medium, provided the original work is properly cited. Copyright (C) 2021 Korean Academy of Physical Therapy Rehabilitation Science 
위험성이 커지게 하여 보행능력 저하로 나타난다. 따라서 뇌졸중 환자의 마비 측 근력을 증진시키면 균형능력의 증진 을 가져오고 이는 보행능력 증진에도 영향을 미친다[8].

만성 뇌졸중 환자들의 근력 증진을 통한 균형능력, 보행 능력의 증진을 위하여 트레드밀 훈련[9, 10], 재활승마훈 련[11], 근력 훈련[12], 전기적 자극[13] 등 여러 가지 방법 이 시도되었다.

이러한 방법 중 전기적 자극은 통증조절과 감각을 자극 하는 경피신경 전기자극(transcutaneous electrical nerve stimulation; TENS)과 신경근 전기자극(neuromuscular electrical stimulation; NMES)으로 사용하는 기능적 전기 자극(functional electrical stimulation; FES)이 만성 뇌졸 중 환자의 재활에 오랫동안 사용되어 왔다. 그 중에서도 $\mathrm{FES}$ 는 중추신경계에서 수의적 움직임을 조절할 수 없는 근육에 근 수축의 역할과 기능적으로 유용한 움직임을 이 끌어 내는 역할을 할 수 있고[14], 특정 근육의 근력증가에 사용될 수 있다[15].

$\mathrm{FES}$ 를 사용한 이전의 연구들을 보면 뇌졸중 환자들의 보행 중 흔히 볼 수 있는 족하수를 개선하기 위해 발 스위 치를 사용하여 FES가 유각기 동안 전경골근을 수축하도 록 하였고 그 결과 보행 속도가 증가하였다고 하였다. 또한 트레드밀 훈련과 함께 $\mathrm{FES}$ 를 적용한 연구에서도 트레드 밀 훈련만을 한 대조군 보다 실험군에서 보행능력이 향상 된 것을 볼 수 있었고[16], 또 다른 연구에서는 척추손상환 자들의 하지 마비 근육에 매일 $\mathrm{FES}$ 를 적용한 1년 후 근육 활성도와 근육의 크기를 측정한 결과 근섬유의 크기가 커 지고 활성도가 증가한 결과를 얻을 수 있었다[17].

뇌졸중 환자들의 균형과 보행을 증진시키기 위해 $\mathrm{FES}$ 를 사용한 이전의 연구들에서는 보행운동과 함께 적용한 방법이 대부분이었고 정적 균형을 증진시킬 수 있는 방법 에 대한 연구가 최근 제시되고 있지만 FES에 일시적 효과 를 보았을 뿐 균형 훈련과 기능적 전기자극을 병행한 치료 방법에 대한 연구가 없었다. 따라서 본 연구를 통해 균형 훈련과 기능적 전기 자극을 병행한 훈련이 만성 뇌졸중 환 자의 자세 균형과 보행에 미치는 효과를 확인 하고자 한다.

\section{연구 방법}

\section{연구 대상}

대상자는 경기도 의정부에 위치한 $\mathrm{B}$ 병원 입원환자 중 뇌졸중으로 인한 편마비 환자로서 유병기간이 6개월 이상 인자, 의사표현이 가능하고, MMSE-K에서 연령과 교육 수준을 고려한 점수가 최소 21점 이상인 자, 발목관절에 구축 없는 자, 적어도 $10 \mathrm{~m}$ 보행이 가능한 자를 대상으로 하였고, 뇌졸중외 다른 질환으로 보행에 영향을 주는 자, 뇌간이나 소뇌 병변인 자는 제외하였다. 대상자에게 본 연
구의 목적을 설명한 후 연구에 동의한 사람만을 대상으로 선정하였다. 연구의 모든 진행은 헬싱키선언에 따라 윤리 기준을 준수하였다. 대상자는 총 9명이 선정되었고 두 가 지 중재를 실행하고 사후평가를 완료할 때까지 탈락자 없 이 실험을 완료하였다.

\section{연구 절차}

본 연구는 교차실험설계(cross over design)로 경기도 의정부에 위치한 $\mathrm{B}$ 병원에 뇌졸중으로 입원한 환자 9 명을 두 그룹으로 나누어 A-B군과 B-A군에 각각 5명, 4명을 배 치하였다. 그룹의 구분은 선정편견을 최소화하기 위해 무 작위로 할당하였다. 훈련 전에 보행능력, 균형능력을 검사 하였고 훈련 4주 후에 전과 동일한 방법으로 검사를 수행 하였다. A-B군은 기능적 전기 자극과 균형 훈련을 실시하 는 기능적 전기 자극 중재(A)를 먼저 4주간 실시하고 이후 위약 전기 자극과 균형 훈련을 실시하는 위약 전기 자극 중 재(B)를 4주간 실시하였다. B-A군은 위약 전기 자극 중재 (B)를 먼저 4주간 실시하고 이후 기능적 전기 자극 중재 (A)를 4주간 실시하였다. 첫 번째 중재가 끝난 후 두 번째 중재가 시작되기 전 2주간의 쉬는 시간을 갖도록 하여 첫 번째 중재의 영향력을 최소화하였다.

두 군은 모두 상지 위주의 기능적 전기 자극 치료와 중 추신경발달치료, 구르기와 같은 기능을 중점으로 한 매트 운동으로 구성된 일반적 물리치료를 수행하였다.

균형훈련의 시간은 $\mathrm{A}-\mathrm{B}$ 군과 $\mathrm{B}-\mathrm{A}$ 군 동일하게 하루에 50 분씩 주당 3 회 4 주간 균형훈련을 수행하였다. 균형운동 은 본 운동 40 분과 시작과 끝에 각각 준비운동과 마무리 운동을 5 분씩 실시하도록 하였다.

\section{실험 방법}

\section{기능적 전기자극}

기능적 전기 자극 중재의 기능적 전기 자극을 위하여 기 능적 전기자극기(Microstim; Medel GmbH, Germany)와 일회용 표면전극(Valutrode; Axelgaard, USA) $(0.5 \times 0.5$ $\mathrm{cm})$ 을 사용하였다.

전기자극의 파형은 대칭 이상 방형파(symmetrical biphasic square), 빈도(frequency)는 $25 \mathrm{~Hz}$, 맥동빈도 (pulse rate)는 35 pps로 하였고, 표면전극은 비복근의 내 외측 근복(muscle bellies)의 가장 둘레가 큰 부위를 중심 으로 근육의 기시점에 가장 가까운 근육 부분에 (-)전극을 부착하였고, 정지점에 가장 가까운 근육 부분에 $(+)$ 전극을 부착하였다. 전류 단속 비는 전류 흐르는 시간 8 초, 전류가 흐르지 않는 시간 10 초였다. 전류 강도는 도수근력검사 (Muscle Manual Test, MMT)에서 Fair 단계로 저측굴곡 근의 근수축이 일어나는 강도를 사용하였고 이 강도는 8 $20 \mathrm{~mA}$ 사이의 분포로 대상자마다 각각 다르게 나타났다[18]. 


\section{균형훈련}

균형 훈련은 Janice J. Eng의 지구력과 가동성 운동 (Fitness and Mobility Exercise Program, FAME) 중에서 균형 훈련을 수정하여 사용하였다[19]. 본 운동 총 6단계 로, 모든 단계는 5 분씩 실시하였고 각 단계 사이마다 2 분 의 휴식시간을 주어 40 분의 시간이 걸리고 훈련 시작과 끝 에는 각각 5 분 동안의 준비운동과 마무리 운동을 하여 총 운동시간 50 분이 소요된다. 균형 훈련은 4 주 동안 연구자 의 감독 하에 주 3 회씩 실시하였다. $\mathrm{FES}$ 를 적용하여 훈련 시에 4번 과정은 전류 통전 시간동안 환측으로 체중이동을 하고 전류가 통전되지 않는 시간 동안 건측으로 체중이동 을 하도록 지시하였고, 5 번 과정에서는 전류 통전 시간동 안 저측굴곡을 하고 전류가 통전되지 않는 시간동안 배측 굴곡을 하도록 지시하였다. 나머지 과정들은 통전과 상관 없이 자세를 유지하도록 지시하였다(Table 3).

\section{위약 전기 자극}

위약 전기 자극 중재군의 균형 훈련 시 기능적 전기 자 극군과 동일한 전기자극기(Microstim; Medel $\mathrm{GmbH}$ inc., Germany)를 자극 없이 부착하기만 하고 기능적 전기 자극군과 동일한 심리적 상태를 유지하도록 하기 위하여 대상자들에게 적은 강도의 전기가 통전되어 느끼지 못할 수 도 있다고 이야기 한다. 기능적 전기 자극기의 위치와 전극의 위치는 기능적 전기 자극군과 동일하게 하였으며, 균형 훈련도 기능적 전기 자극군과 동일하게 적용하였다.

\section{일반적 물리치료}

일반적 물리치료는 기능적 전기자극, 중추신경발달치 료, 매트운동을 말하며 기능적 전기자극 20 분, 중추신경발 달치료 30 분, 매트 운동 30 분씩 매일 실시하는 물리치료이 다. 실험에 영향을 주지 않도록 상지에 기능적 전기자극을 주고 중추신경발달치료와 매트운동 또한 상지위주의 운동 을 실시했으며, 기능적 전기자극 중재와 위약 전기 자극 중 재 모두 동일하게 적용하였다.

\section{측정 도구와 자료수집과정}

\section{정적 균형능력 검사}

정적 균형능력을 측정하기 위한 방법으로 Good Balance System(Good Balance System; Metitur Ltd, Finland)을 사용하였다. 이 장비는 이동이 가능한 삼각형 의 두발 기립용 발판으로 구성되어 있고 발판위에는 적절 한 발의 위치를 위해서 눈금자가 표시되어 있으며, 균형의 문제점이나 재활의 결과를 알아보기 위해 사용되고 자세 동요와 체중 지지율 및 되먹임 기전을 이용한 훈련에도 사 용된다.

이 장비는 선수나 노인, 뇌졸중 환자뿐 만 아니라 반신
마비 환자의 균형을 측정하는 장비로 널리 사용되었으며 $[20,21]$, 근거리 무선 통신(Bluetooth)의 기능을 사용하고 있다. 검사-재검사 방법에서 측정자 내 상관 계수 $(\mathrm{ICC}=0.83)$ 는 0.83 이상으로 높은 신뢰도가 입증되었다.

대상자는 장비 위에 정적인 상태로 서서 눈을 뜬 상태로 30 초간 전방을 향해 서 있도록 하며 3 회 측정하였다. 그 다 음 눈을 감은 상태로 30 초간 전방을 향해 서 있도록 하며 3 회 측정하였다. 30 초간 눈을 뜨고 감은 상태에서 좌우와 전후의 동요거리를 측정 하여 단위는 $\mathrm{mm}$ 로 표시하였고, 속도 모멘트를 측정하여 단위는 $\mathrm{mm}^{2} / \mathrm{s}$ 로 표시하였다.

\section{동적 균형능력 검사}

\section{일어나 걸어가기 검사(Timed Up and Go Test, TUG)}

$\mathrm{TUG}$ 는 뇌졸중 환자의 동적 균형능력을 평가하기 위해 사용되었다[22, 23]. TUG는 일어나기, $3 \mathrm{~m}$ 걷기,돌아오 기, 앉기로 구성되어있는 간단하고 빠르게 기능적 움직임 을 검사하는 것이다. 측정방법은 팔걸이와 등받이가 있는 의자에서 앉아 있다가 일어나 3 미터 걸어간 뒤 다시 의자 로 돌아와 앉을때까지 걸리는 시간을 측정하는 것으로 경 직과 같은 하지 장애를 지닌 뇌졸중 환자에게 동적 균형이 나 기능적 움직임, 보행능력을 평가하는데 신뢰도와 타당 도가 높은 평가방법이다[24]( $\mathrm{ICC}=0.99)$. 본 실험에서는 $50 \mathrm{~cm}$ 높이의 의자를 사용하여 측정하였고, 측정자는 초시 계로 3 번 측정하여 평균값을 기록하였다.

\section{기능적 팔 뻗기(Functional Reach Test, FRT)}

FRT는 안정성의 한계를 평가한다[23]. 측정 방법은 대 상자는 벽 옆에 $10 \mathrm{~cm}$ 정도 떨어진 위치에서 서서 주먹을 쥔 상태로 어깨를 90도 굴곡 시킨 후 팔을 바닥에 평행한 방향으로 최대한 앞으로 뻗게 하여 중수지절관절 끝의 이 동 거리를 측정한다. 평가-재평가 신뢰도와 측정자간 신뢰 도는 각각 $\mathrm{r}=0.89, \mathrm{r}=0.98$ 로 높은 수준이다 $[25,26]$. 본 실 험에서 3회 측정하여 평균값을 기록하였다.

\section{버그 균형 척도(Berg balance scale, BBS)}

버그 균형 척도는 뇌졸중 후 환자나 노인의 균형 능력을 측정하는 방법으로써[23], 앉은 자세의 균형과 같이 낮은 단계에서 한발로 서기나 한발 떼기와 같은 높은 단계로 이 루어진 14개의 과제수행능력을 평가하며[27], 14개 항목 은 앉은 자세에서 일어나기, 잡지 않고 서 있기, 의자의 등 받이에 기대지 않고 바른 자세로 앉기, 선 자세에서 앉기, 의자에서 의자로 이동하기, 두 눈을 감고 잡지 않고 서 있 기, 두 발을 붙이고 잡지 않고 서 있기, 선 자세에서 앞으로 팔을 뻗쳐 내밀기, 바닥에 있는 물건을 집어 올리기, 왼쪽 과 오른쪽으로 뒤돌아보기, 제자리에서 $360^{\circ}$ 회전하기, 일정한 높이의 발판 위에 발을 교대로 놓기, 한 발 앞에 다 
른 발을 일자로 두고 서 있기 그리고 한 다리로 서 있기로 되어 있다. 14 개의 항목을 수행하는데 0 점부터 4점까지의 5점 척도로 구성되었으며 총 56점 만점으로 구성되어 있 다[28]. 이 측정도구는 측정자 내 신뢰도와 측정자간 신뢰 도가 각각 $\mathrm{r}=0.99, \mathrm{r}=0.98$ 로서 균형 능력을 평가하는데 높 은 신뢰도와 내적 타당도를 가지고 있다[29, 30]. Fugl-Meyer Scale의 균형과 유의한 결과 치를 보여주어 타당도가 검증된 균형 측정 방법이며[31], 높은 신뢰도와 타당도가 검증되어 뇌졸중 환자나 노인의 균형능력을 측 정하는데 쓰인다[32](ICC=0.97). 본 실험에서 14 개 항목 을 충분히 설명 한 후 각각 1 회씩 측정하여 점수를 계산 하 였고 사전, 사후 검사 모두 동일한 연구자가 측정하였다.

\section{보행 검사}

보행 검사는 환자의 보행 유형에 대한 양적인 보행 분석 의 자료를 수집하기 위하여 보행분석기(GAITRite; CIR system Inc, USA)를 이용하여 시간적, 공간적 보행 능력 을 측정하였다[33].

보행분석기는 길이 $5 \mathrm{~m}$, 폭 $61 \mathrm{~cm}$, 높이 $0.6 \mathrm{~cm}$ 인 전자 식 보행판으로, 직경 $1 \mathrm{~cm}$ 의 16,128 개의 센서가 $1.27 \mathrm{~cm}$ 마 다 보행판을 따라 수직으로 배열되어 시간적, 공간적 변수 에 대한 정보를 수집한다. 수집된 시간적, 공간적 변수에 대한 정보는 GAITRite GOLD(Version 3.2; CIR system Inc, USA) 소프트웨어로 처리를 하였다. 실험은 대상자를 보행판 전방에 서 있도록 한 다음, 검사자의 구두신호에 의 하여 가장 편안한 보행 속도로 걸어서 보행판 밖으로 나오 면 된다.

측정은 보행속도(velocity), 분속수(cadence)를 측정하 였다. 이 검사의 측정자 신뢰도는 $\mathrm{r}=0.90$ 이고 편안한 보행 속도의 모든 보행 측정값 내 상관계수 $(\mathrm{ICC}=0.99)$ 는 0.96 이상이다[34].

\section{통계 분석}

본 연구는 SPSS(ver. 19)를 이용하여 통계 분석을 하였 다. 훈련 전 정규성 검정을 실시하였고 정규분포 가정을 만족하여 중재 간 차이를 보기 위해 독립표본 t-검정을 이 용하였으며, 자료의 모든 통계학적 유의수준은 0.05 로 하 였다.

\section{연구결과}

\section{연구 대상자의 일반적 특성}

훈련을 완료한 9 명중 남자는 7 명, 여자는 2 명이었다. 대 상자의 마비측은 우측 편마비가 5명, 좌측 편마비가 4명 이었고 평균 연령은 49.44세이었다. 신장은 $167.89 \mathrm{~cm}$ 이 었고, 체중은 $69.89 \mathrm{~kg}$ 이었다(Table 1).

\section{연구대상자의 초기 균형능력과 보행능력}

훈련 전 연구 대상자들의 초기 정적 균형능력은 눈 뜬 상태에서 전후 자세동요 거리는 $223.75 \mathrm{~mm}$ 이었고, 내외 측 자세동요 거리는 $316.80 \mathrm{~mm}$ 이었으며, 속도 모멘트는 $30.48 \mathrm{~mm}^{2} / \mathrm{s}$ 이었다. 눈 감은 상태에서는 전후 자세동요 거 리는 $399.24 \mathrm{~mm}$ 이었고, 내외측 자세동요 거리는 517.26 $\mathrm{mm}$ 이었으며, 속도 모멘트는 $68.75 \mathrm{~mm}^{2} / \mathrm{s}$ 이었다. 초기 동 적 균형능력은 $\mathrm{TUG}$ 가 21.71초였고, $\mathrm{FRT}$ 가 $15.66 \mathrm{~cm}$ 이 었으며, BBS가 44.11점이었다. 초기 보행능력에서는 보행 속도가 $53.91 \mathrm{~cm} / \mathrm{s}$ 이었고, 분속수가 $80.63 \mathrm{steps} / \mathrm{min}$ 이었 다 (Table 2).

Table 1. General Characteristics of Participants

$(n=9)$

\begin{tabular}{ll}
\hline Characteristics & mean \pm SD \\
\hline Sex (male/female) & $7 / 2$ \\
$\begin{array}{l}\text { Paretic side (right/left) } \\
\text { Type of stroke }\end{array}$ & $6 / 3$ \\
(Infarction/Hemorrhage) & $5 / 4$ \\
Age (years) & $49.44 \pm 5.548$ \\
Height $(\mathrm{cm})$ & $167.89 \pm 9.253$ \\
Weight $(\mathrm{kg})$ & $69.89 \pm 10.971$ \\
\hline
\end{tabular}

Table 2. Pre-test of balance abilities and gait abilities $(n=9)$

\begin{tabular}{ll}
\hline & $\begin{array}{l}\text { Participants } \\
\text { mean } \pm \text { SD }\end{array}$ \\
\hline Static balance abilities (eye open) & \\
AP (mm) & $223.75 \pm 90.65$ \\
ML (mm) & $316.80 \pm 84.40$ \\
VM (mm $/ \mathrm{s})$ & $30.48 \pm 18.61$ \\
\hline Static balance abilities (eye close) & \\
AP (mm) & $399.24 \pm 350.51$ \\
ML (mm) & $517.26 \pm 263.44$ \\
VM (mm $/ \mathrm{s})$ & $68.75 \pm 76.08$ \\
\hline Dynamic balance abilities & $21.71 \pm 11.07$ \\
TUG (sec) & $15.66 \pm 3.01$ \\
FRT (cm) & $44.11 \pm 5.21$ \\
BBS (score) & \\
\hline Gait abilities & $53.91 \pm 34.13$ \\
Speed (cm/s) & $80.63 \pm 19.56$ \\
Cadence (steps/min) & \\
\hline AP: anteriorposterior extension, ML: mediolateral extension, \\
VM: velocity moment \\
TUG: timed up and go, FRT: functional reach test, BBS: \\
Berg balance scale & \\
& \\
\hline
\end{tabular}




\section{균형 및 보행능력 변화}

\section{정적 균형능력의 전·후 변화}

눈을 뜬 상태에서의 전후 자세동요 거리에서 $\mathrm{FES}$ 중재 일 때 훈련 전에서 훈련 후 $30.16 \mathrm{~mm}$ 감소하였고, placebo $\mathrm{FES}$ 중재일 때는 훈련 전에서 훈련 후 $2.17 \mathrm{~mm}$ 증가하였 다. 두 중재 간의 훈련 전·후 변화량은 유의한 차이를 보이 지 않았다.

눈을 뜬 상태에서의 내외측 자세동요 거리에서 $\mathrm{FES}$ 중 재일 때 훈련 전에서 훈련 후 $42.90 \mathrm{~mm}$ 감소하였고, placebo FES 중재일 때 훈련 전에서 훈련 후 $30.29 \mathrm{~mm}$ 감 소했다. 두 중재 간의 훈련 전·후 변화량은 유의한 차이를 보이지 않았다.

눈을 뜬 상태에서의 속도 모멘트에서 $\mathrm{FES}$ 중재일 때 훈련 전 에서 훈련 후 $3.83 \mathrm{~mm}^{2} / \mathrm{s}$ 감소하였고 $(\mathrm{p}<0.05)$, placebo FES 중재일 때 훈련 전 에서 훈련 후 $2.55 \mathrm{~mm}^{2} / \mathrm{s}$ 감소했다. 두 중재 간의 훈련 전·후 변화량은 유의한 차이 를 보이지 않았다 (Table 3).

눈을 감은 상태에서의 전후 자세동요 거리에서 $\mathrm{FES}$ 중 재일 때 훈련 전에서 훈련 후 $46.66 \mathrm{~mm}$ 감소하였고, placebo FES 중재일 때는 훈련 전에서 훈련 후 $4.11 \mathrm{~mm}$ 감소했다. 두 중재간의 훈련 전·후 변화량은 유의한 차이 를 보이지 않았다.

눈을 감은 상태에서의 내외측 자세동요 거리에서 $\mathrm{FES}$ 중재일 때 훈련 전에서 훈련 후 $88.13 \mathrm{~mm}$ 감소하였고, placebo FES 중재일 때는 훈련 전에서 훈련 후 $9.86 \mathrm{~mm}$ 감소했다. 중재 간의 훈련 전·후 변화량은 유의한 차이를 보였다 $(\mathrm{p}<0.05)$.

눈을 감은 상태에서의 속도 모멘트에서 $\mathrm{FES}$ 중재일 때 훈련 전에서 훈련 후 $14.98 \mathrm{~mm}^{2} / \mathrm{s}$ 감소하였고, placebo $\mathrm{FES}$ 중재일 때는 훈련 전에서 훈련 후 $6.24 \mathrm{~mm}^{2} / \mathrm{s}$ 감소했 다. 두 중재 간의 훈련 전·후 변화량은 유의한 차이를 보이
지 않았다 (Table 3).

\section{동적 균형능력의 전·후 변화}

TUG에서 FES 중재일 때 훈련 전에서 훈련 후 1.73 초 감소하였고, placebo FES 중재일 때는 훈련 전에서 훈련 후 0.64초 감소했다. 두 중재 간의 훈련 전·후 변화량은 유 의한 차이를 보이지 않았다.

FRT에서 FES 중재일 때 훈련 전에서 훈련 후 $3.26 \mathrm{~cm}$ 증가하였고, placebo FES 중재일 때도 훈련 전에서 훈련 후 $1.18 \mathrm{~cm}$ 증가하였다. 두 중재 간의 훈련 전·후 변화량 은 유의한 차이를 보였다( $\mathrm{p}<0.05)$.

$\mathrm{BBS}$ 에서 $\mathrm{FES}$ 중재일 때 훈련 전에서 훈련 후 3.11점 증가하였고, placebo FES 중재일 때도 훈련 전에서 훈련 후 1.22 점 증가하였다. 두 중재 간의 훈련 전·후 변화량 또 한 유의한 차이를 보였다 $(\mathrm{p}<0.05)$ (Table 3$)$.

\section{보행능력 전·후 변화}

보행속도에서 FES 중재일 때 훈련 전에서 훈련 후 3.36 $\mathrm{cm} / \mathrm{s}$ 증가하였고, placebo FES 중재일 때는 훈련 전에서 훈련 후 $0.03 \mathrm{~cm} / \mathrm{s}$ 감소하였다. 두 중재 간의 훈련 전·후 변화량은 유의한 차이를 보였다 $(\mathrm{p}<0.05)$.

분속수에서 $\mathrm{FES}$ 중재일 때 훈련 전에서 훈련 후 3.93 steps/min 증가하였고, placebo FES 중재일 때는 훈련 전 에서 훈련 후 $1.87 \mathrm{steps} / \mathrm{min}$ 감소하였다. 두 중재 간의 훈련 전·후 변화량은 유의한 차이를 보였다( $\mathrm{p}<0.05)$ (Table 4).

\section{고찰}

본 연구는 $\mathrm{FES}$ 를 병행한 운동이 만성 뇌졸중 환자의 균 형 및 보행능력에 영향을 주는지 알아보고 만성 뇌졸중 환 자의 기능향상을 위한 접근법을 제시하기 위하여 시행되 었다. FES를 병행한 운동을 4주간 시행 후 만성 뇌졸중 환

Table 3. Changes in balance abilities

$(\mathrm{n}=18)$

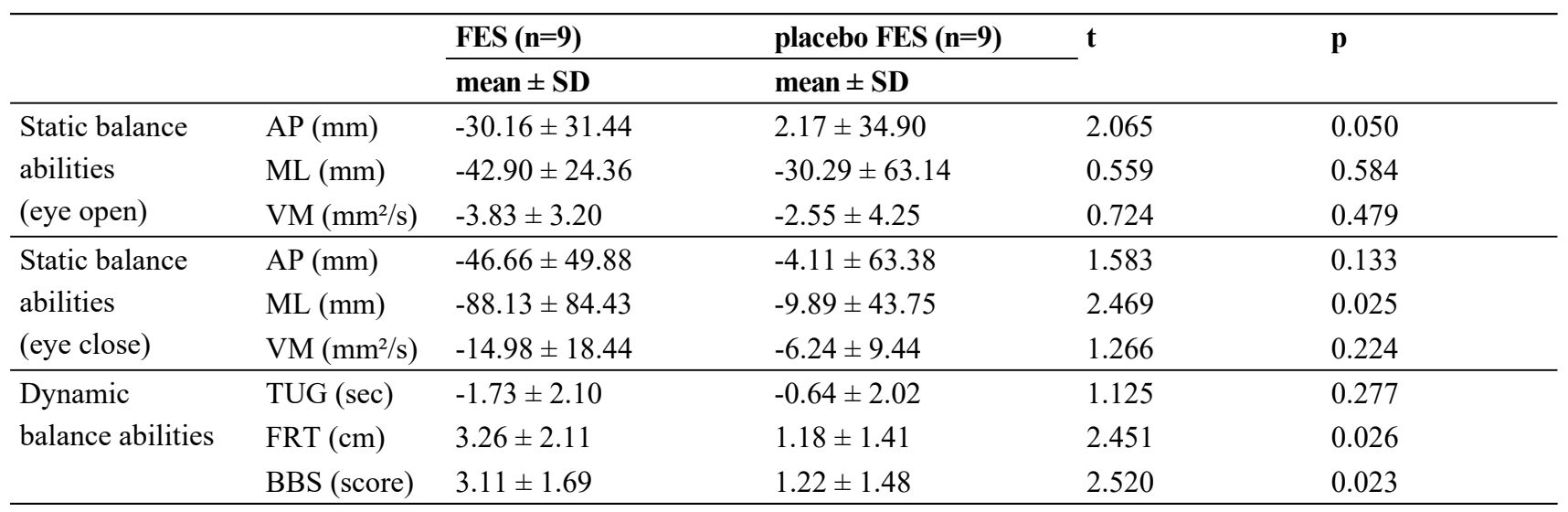

AP: anteriorposterior extension, ML: mediolateral extension, VM: velocity moment

TUG: timed up and go, FRT: functional reach test, BBS: Berg balance scale 
Table 4. Changes in gait abilities

$(\mathrm{n}=18)$

\begin{tabular}{|c|c|c|c|c|c|}
\hline & & \multirow{2}{*}{$\begin{array}{l}\text { FES }(n=9) \\
\text { mean } \pm \text { SD }\end{array}$} & \multirow{2}{*}{$\begin{array}{l}\text { placebo FES }(n=9) \\
\text { mean } \pm \text { SD }\end{array}$} & \multirow[t]{2}{*}{$\mathbf{t}$} & \multirow[t]{2}{*}{$\mathbf{p}$} \\
\hline & & & & & \\
\hline Gait balance & Speed $(\mathrm{cm} / \mathrm{s})$ & $3.36 \pm 2.08$ & $-0.03 \pm 4.16$ & 2.186 & 0.044 \\
\hline abilities & Cadence (steps/min) & $3.93 \pm 4.48$ & $-1.87 \pm 3.27$ & 2.978 & 0.009 \\
\hline
\end{tabular}

자의 균형 및 보행능력에 미치는 영향에 대해 알아보기 위 해 정적 균형능력, 동적 균형능력, 보행변수를 분석하였다.

전기적인 감각자극은 뇌졸중 환자의 보행과 균형의 증 진을 위해 오랫동안 쓰이고 있다. FES와 TENS는 근력과 운동 수행능력을 증가시키고 강직을 감소시킨다는 점에서 비슷하지만, $\mathrm{FES}$ 는 TENS 보다 더 강한 근육의 수축과 관 절 움직임을 생성할 수 있다[35]. 따라서 $\mathrm{FES}$ 는 운동조절 과 기능의 증진, 근력의 증진, 관절 각도의 증진, 강직의 감 소에 효과적이며 능동적인 운동조절 능력을 향상시킬 수 있다[36].

$\mathrm{FES}$ 의 치료적 기전은 중추신경계의 구심성 신경 입력 을 증가시켜 신경가소성을 촉진시키는 것이다. 이는 기능 적으로 존재했지만 사용하지 않았던 신경 접합을 활동시 키거나 그들이 가지고 있는 억제를 중단시켜서 활동하도 록 한다[37]. 이전의 연구에서 손목 신전이 일어나도록 전 기적 자극을 주었을 때 대뇌의 체성감각 피질과 보조 운동 영역의 활동을 기능성 자기공명장치를 통해 확인하였고 [38], 피질의 활동이 증가하면 기능 증진이 동반된다고 하 였다[39]. 이러한 연구들은 전기 자극을 주어 움직임을 반 복하면 운동 재교육이 일어나게 되고 이로 인해 중추 신경 가소성이 일어난다고 추측하였다.

또한 $\mathrm{FES}$ 는 근육의 수축을 일어나게 하는데 이 전기 자 극 동안에 능동적인 수축력이 함께 일어나게 되면 약해진 근육의 근력이 증가한다고 하였다[40]. 따라서 현재 FES 는 중추신경계장애를 가진 환자들의 마비 근육에 직접적 으로 적용되고 있으며[41], 자극 효과를 높이기 위하여 환 자에게 가능하면 움직임을 같이 하도록 권장하고 있다. 임 상에서도 움직임과 함께 $\mathrm{FES}$ 를 적용함으로서 마비근육의 능동적인 수축력이 전기자극 효과를 높일 수 있을 것 이라 고 생각한다.

우리가 일상생활에서 앉거나 서거나 혹은 걷는 것과 같 이 독립적인 활동이 가능한 이유는 균형을 유지하고 조절 할 수 있기 때문이다. 균형을 유지하고 조절 한다는 것은 근골격계와 신경계가 원활히 작동하고 있다는 것을 의미 한다. 다시 말해 근력, 관절가동범위, 척추가동성, 근육 탄 성, 각 분절 사이의 역학적 정렬과 같은 근골격계 요소와 운동 처리 과정, 감각, 지각 처리 과정, 선행적, 적응적 자 세 조절과 같은 신경계 요소가 복합적으로 작용한다는 것 이다[42]. 그러나 뇌졸중 환자들은 균형 조절의 장애를 가
지고 있으며 이는 근력의 약화, 근 수축 타이밍 문제, 감각 소실, 비정상적인 근 긴장도, 선행적 자세 조절의 소실, 그 리고 2 차적으로 나타나는 근 단축, 근 위축, 관절가동범위 의 제한, 생역학적인 정렬상태의 변화와 같은 문제들로 나 타난다[4]. 임상에서 뇌졸중 환자들의 서 있는 자세를 보면 양 하지의 체중지지가 불균형 한 것을 흔히 볼 수 있다. 마 비 측 하지의 근 약화로 인해 마비 측 하지로 체중 지지를 하지 못하는 것이고 이로 인해 균형을 유지 하지 못하고 보 행을 시작하는데 어려움을 느끼게 된다. 뇌졸중 환자들의 균형능력 증진은 서있는 자세에서 양 하지에 균등한 체중 지지를 할 수 있도록 하는 것부터 시작되어야 한다고 생각 한다.

이전의 연구에서 뇌졸중 환자들의 균형능력 증진을 위 해 FES를 적용한 연구들이 있었다. Georg 등 [43]은 만성 뇌졸중 환자 한 그룹을 대상으로 흔들림이 일어나도록 하 는 균형 훈련장비 위에 서서 균형을 유지 하도록 하며 하지 의 근육에 $\mathrm{FES}$ 를 1 회 적용 한 후와 균형을 유지 하도록 지 시만 한 후의 데이터를 비교하였다. 그 결과 $\mathrm{FES}$ 를 1회 적 용 한 시점에서 자세동요가 감소하였다. 이는 $\mathrm{FES}$ 가 균형 을 유지하는 근육의 수축을 활성화 하고 수축 타이밍을 조 절하여 균형을 증진시킬 수 있을 거라고 예측하였다. Tortolero 등 [18]은 정상인을 대상으로 FES를 발가락 굽 힘근에 적용하고 선 자세에서 압력중심점(center of pressure)의 움직임과 속도를 측정하여 FES 적용 전과 적 용 후의 균형 조절력을 측정하였다. 결과는 $\mathrm{FES}$ 적용 전에 는 압력중심점이 앞쪽방향으로 이동하려는 모습이 보였고 FES 적용 후에는 압력중심점이 뒤쪽으로 되돌아오는 모 습을 보여 근육에 적용된 $\mathrm{FES}$ 가 근육의 활동을 증가시켜 발목관절의 안정성에 기여한 것이라는 결론을 얻었다. 그 러나 기존의 연구들에서는 $\mathrm{FES}$ 를 적용한 후의 일시적 모 습만 관찰 하였을 뿐 지속적 효과에 대해서는 연구하지 않 았고, 훈련과 $\mathrm{FES}$ 를 병행한 방법에 대한 연구는 없었다.

본 연구에서는 $\mathrm{FES}$ 를 이용하여 만성 뇌졸중 환자의 비 복근에 $25 \mathrm{~Hz}$ 의 자극을 주는 것과 동시에 균형 훈련을 실 시하였고 4주 후 균형능력의 중재 전·후 변화를 알아보기 위해 균형 측정 장비를 사용하여 전후, 내 외측 자세동요 거 리, 속도 모멘트와 같은 정적 균형능력을 측정하였으며, TUG, FRT, BBS를 실시하여 동적 균형능력을 측정하였다.

$\mathrm{FES}$ 를 병행한 균형 훈련을 실시했을 때 전후, 내외측 
자세동요 거리, 속도 모멘트, TUG, FRT, BBS 모두 차이 가 있었으며, 두 중재간의 훈련 전·후 변화량은 유의한 차 이를 보였다( $\mathrm{p}<0.05) . \mathrm{FES}$ 를 병행한 균형 훈련이 약화된 비복근의 근 활성을 증가 시켜 마비 측 하지로의 체중 지지 를 증가시키고 발목 관절의 안정성을 증가시켜 균형능력 의 향상을 가져온 것으로 생각한다.

또한 본 연구에서 보행능력의 중재 전·후 변화를 알아 보기 위해 보행 측정 장비를 사용하였고, 보행 속도와 분속 수를 측정하였다.

$\mathrm{FES}$ 를 병행한 균형훈련을 실시한 실험군에서 보행속 도, 분속수 모두 차이가 있었으며, 두 중재간의 훈련 전·후 변화량은 유의한 차이를 보였다 $(\mathrm{p}<0.05)$.

보행 속도는 뇌졸중 환자의 운동기능의 여러 요소와 연 관 되어있는데, 특히, 환측 하지에 발생하는 근 약화는 운 동 단위 수 감소, 운동 단위 활성율 감소 등이 원인이며 [44], 이러한 변화가 보행 속도 감소에 직접적인 영향을 미 친다고 하였다[45]. 따라서 본 연구에서 FES의 적용이 근 육 수축을 유도하여 운동 단위 활성을 일으켰고 이로써 보 행 속도가 향상되었고, 분속수도 증가 시켰다고 생각한다.

$\mathrm{FES}$ 를 이용한 선행연구 중 대부분이 보행능력을 측정 하거나 척수 손상 환자들의 정적 균형 능력을 측정한 결과 만 있을 뿐 뇌졸중 환자의 균형 증진 위한 균형 훈련과 함 께 $\mathrm{FES}$ 를 적용한 실험은 찾아 볼 수 없었다. 따라서 본 연 구는 뇌졸중 환자의 재활 목표가 되는 균형 증진에 효과적 인 중재를 제안했다고 사료된다. 또한 임상에서 환자들의 $\mathrm{FES}$ 적용은 능동적 근 수축을 함께 동반하기 보다는 전기 적 자극에 의한 수축에만 의존하고 있다. 따라서 본 연구에 서와 같이 균형훈련과 함께 적용되어 진다면 능동적 근 수 축이 동반 되어져 근 수축 활성과 근재교육의 효과는 더욱 커질 것으로 생각한다.

반면 본 연구의 제한점은 실험 대상자의 수가 적고 FES 의 효과가 얼마나 지속가능한지 알아보지 못했다는 것이 다. 추후 연구에서는 대상자 수를 늘리고 FES 효과 지속성 에 대한 연구가 필요할 것으로 생각한다.

\section{결론}

본 연구의 결과를 통하여 $\mathrm{FES}$ 를 병행한 균형훈련이 만 성 뇌졸중 균형능력, 보행능력을 향상시킴으로써 기능적 활동을 증진시키는데 효과적인 중재방법으로 임상에서 적 극적으로 활용할 수 있을 것으로 생각한다.

\section{이해 충돌}

본 연구의 저자들은 연구, 저자권, 및 출판과 관련하여 잠재적인 이해충돌이 없음을 선언합니다.

\section{참고문헌}

1. Campbell BCV, Khatri P. Stroke. Lancet. 2020;396: $129-42$.

2. Sturm JW, Dewey HM, Donnan GA, Macdonell RAL, McNeil JJ, Thrift AG. Handicap after stroke: How does it relate to disability, perception of recovery, and stroke subtype? The North East Melbourne Stroke Incidence Study (NEMESIS). Stroke. 2002; 33:762-8.

3. Nyberg L, Gustafson Y. Patient Falls in Stroke Rehabilitation A Challenge to Rehabilitation Strategies. Stroke. 1995;26:838-42.

4. Bonan IV, Colle FM, Guichard JP, Vicaut E, Eisenfisz M, Tran Ba Huy P, et al. Reliance on visual information after stroke. Part I: Balance on dynamic posturography. Arch Phys Med Rehabil. 2004;85:268-73.

5. Orr R. Contribution of muscle weakness to postural instability in the elderly. A systematic review. Eur J Phys Rehabil Med. 2010;46:183-220.

6. Macko RF, Benvenuti F, Stanhope S, Macellari V, Taviani A, Nesi B, et al. Adaptive physical activity improves mobility function and quality of life in chronic hemiparesis. J Rehabil Res Dev. 2008;45: 323-8

7. Horak FB. Postural orientation and equilibrium: what do we need to know about neural control of balance to prevent falls? Age Ageing. 2006;35:7-11.

8. Lamb SE, Ferrucci L, Volapto S, Fried LP, Guralnik $\mathrm{JM}$, Women's $\mathrm{H}$, et al. Risk factors for falling in home-dwelling older women with stroke: the Women's Health and Aging Study. Stroke. 2003;34: 494-501.

9. Lau KW, Mak MK. Speed-dependent treadmill training is effective to improve gait and balance performance in patients with sub-acute stroke. J Rehabil Med. 2011;43:709-13.

10. Maguire C, Sieben JM, Erzer F, Goepfert B, Frank $\mathrm{M}$, Ferber G, et al. How to improve walking, balance and social participation following stroke: a comparison of the long term effects of two walking aids--canes and an orthosis TheraTogs--on the recovery of gait following acute stroke. A study proto- 
col for a multi-centre, single blind, randomised control trial. BMC Neurol. 2012;12:18.

11. Beinotti Correia NCG, Borges GF. Use of hippotherapy in gait training for hemiparetic post-stroke. Arq Neuropsiquiatr. 2010;68:908-13.

12. Yang YR, Wang RY, Lin KH, Chu MY, Chan RC. Task-oriented progressive resistance strength training improves muscle strength and functional performance in individuals with stroke. Clin Rehabil. 2006;20:860-70.

13. Teasell RW, Bhogal SK, Foley NC, Speechley MR. Gait retraining post stroke. Top Stroke Rehabil. 2003;10:34-65.

14. Bajd T, Kralj, A., Turk, R., Benko, H., \& Sega, J. Use of functional electrical stimulation in the rehabilitation of patients with incomplete spinal cord injuries. J Biomed Eng. 1989;11:96-102.

15. Glanz M, Klawansky S, Stason W, Berkey C, Chalmers TC. Functional electrostimulation in poststroke rehabilitation: a meta-analysis of the randomized controlled trials. Arch Phys Med Rehabil. 1996;77:549-53.

16. Daly JJ, Roenigk K, Holcomb J, Rogers JM, Butler $\mathrm{K}$, Gansen J, et al. A randomized controlled trial of functional neuromuscular stimulation in chronic stroke subjects. Stroke. 2006;37:172-8.

17. Kern H, Carraro U, Adami N, Hofer C, Loefler S, Vogelauer M, et al. One year of home-based daily FES in complete lower motor neuron paraplegia: recovery of tetanic contractility drives the structural improvements of denervated muscle. Neurol Res. 2010;32:5-12.

18. Tortolero X, Masani K, Maluly C, Popovic MR. Body movement induced by electrical stimulation of toe muscles during standing. Artif Organs. 2008;32:5-12.

19. Eng JJ. Fitness and Mobility Exercise (FAME) Program for stroke. Top Geriatr Rehabil. 2010;26: 310-23.

20. John LT, Cherian B, Babu A. Postural control and fear of falling in persons with low-level paraplegia. $J$ Rehabil Res Dev. 2010;47:497-502.

21. Mononen K, Viitasalo JT, Konttinen N, Era P. The effects of augmented kinematic feedback on motor skill learning in rifle shooting. J Sports Sci. 2003;21:867-76.

22. Young-Lan Son J-WK. The Effects of Action Observation Training on Lower Limb Muscle Activity and Dynamic Balance in Chronic Stroke Patients. J Phys Ther Sci. 2018;30:1241-4.

23. SoRa Kil SS. Effects of the Motivation for Rehabilitation on the Functional Performance of Stroke Patients. J Kor Phys Ther. 2020;32:39-43.

24. Ng SS, Hui-Chan CW. The timed up \& go test: its reliability and association with lower-limb impairments and locomotor capacities in people with chronic stroke. Arch Phys Med Rehabil. 2005;86: 1641-7.

25. Duncan PW, Weiner DK, Chandler J, Studenski S. Functional reach: a new clinical measure of balance. J Gerontol. 1990;45:M192-7.

26. Katz-Leurer M, Fisher I, Neeb M, Schwartz I, Carmeli E. Reliability and validity of the modified functional reach test at the sub-acute stage post-stroke. Disabil Rehabil. 2009;31:243-8.

27. Wee JY, Wong H, Palepu A. Validation of the Berg Balance Scale as a predictor of length of stay and discharge destination in stroke rehabilitation. Arch Phys Med Rehabil. 2003;84:731-5.

28. Berg Wood-Dauphinee S, Williams JIK. The Balance Scale: reliability assessment with elderly residents and patients with an acute stroke. Scand J Rehabil Med. 1995;27:27-36.

29. Berg KO, Wood-Dauphinee SL, Williams JI, Maki B. Measuring balance in the elderly: validation of an instrument. Can J Public Health. 1992;83 Suppl 2:S7-11.

30. L D Bogle Thorbahn RAN. Use of the Berg Balance Test to predict falls in elderly persons. Phys Ther. 1996;76:576-83.

31. de Oliveira R, Cacho EW, Borges G. Post-stroke motor and functional evaluations: a clinical correlation using Fugl-Meyer assessment scale, Berg balance scale and Barthel index. Arq Neuropsiquiatr. 2006;64:731-5.

32. Conradsson M, Lundin-Olsson L, Lindelof N, 
Littbrand H, Malmqvist L, Gustafson Y, et al. Berg balance scale: intrarater test-retest reliability among older people dependent in activities of daily living and living in residential care facilities. Phys Ther. 2007;87:1155-63.

33. McDonough AL, Batavia M, Chen FC, Kwon S, Ziai J. The validity and reliability of the GAITRite system's measurements: A preliminary evaluation. Arch Phys Med Rehabil. 2001;82:419-25.

34. van Uden CJ, Besser MP. Test-retest reliability of temporal and spatial gait characteristics measured with an instrumented walkway system (GAITRite). BMC Musculoskelet Disord. 2004;5:13.

35. Yan T, Hui-Chan CW, Li LS. Functional electrical stimulation improves motor recovery of the lower extremity and walking ability of subjects with first acute stroke: a randomized placebo-controlled trial. Stroke. 2005;36:80-5.

36. Schuhfried O, Crevenna R, Fialka-Moser V, Paternostro-Sluga T. Non-invasive neuromuscular electrical stimulation in patients with central nervous system lesions: an educational review. J Rehabil Med. 2012;44:99-105.

37. Weingarden H, Ring H. Functional electrical stimulation-induced neural changes and recovery after stroke. Eura Medicophys. 2006;42:87-90.

38. Shin HK, Cho SH, Jeon HS, Lee YH, Song JC, Jang $\mathrm{SH}$, et al. Cortical effect and functional recovery by the electromyography-triggered neuromuscular stimulation in chronic stroke patients. Neurosci Lett. 2008;442:174-9.

39. Kimberley TJ, Lewis SM, Auerbach EJ, Dorsey LL, Lojovich JM, Carey JR. Electrical stimulation driving functional improvements and cortical changes in subjects with stroke. Exp Brain Res. 2004;154:450-60.

40. Chae J. Neuromuscular electrical stimulation for motor relearning in hemiparesis. Phys Med Rehabil Clin N Am. 2003;14:S93-109.

41. Powell J, Pandyan AD, Granat M, Cameron M, Stott DJ. Electrical stimulation of wrist extensors in poststroke hemiplegia. Stroke. 1999;30:1384-9.

42. Shumway-Cook A, Woollacott MH. Motor control. Philadelphia: Lippincott Williams \& Wilkins; 2007.
43. Worms G, Matjacic Z, Gollee H, Cikajlo I, Goljar N, Hunt KJ. Dynamic balance training with sensory electrical stimulation in chronic stroke patients. Conf Proc IEEE Eng Med Biol Soc. 2006;2006:2150-3.

44. Kim CM, Eng JJ. The relationship of lower-extremity muscle torque to locomotor performance in people with stroke. Phys Ther. 2003;83:49-57.

45. Nadeau S, Gravel D, Arsenault AB, Bourbonnais D. Plantarflexor weakness as a limiting factor of gait speed in stroke subjects and the compensating role of hip flexors. Clin Biomech (Bristol, Avon). 1999; $14: 125-35$ 